\title{
Pulmonary valve-sparing techniques during repair of tetralogy of Fallot: The delamination plasty
}

\author{
Vladimiro L. Vida, MD, PhD, Fabio Zucchetta, MD, and Giovanni Stellin, MD
}

\footnotetext{
From the Pediatric and Congenital Cardiac Surgery Unit, Department of Cardiac, Thoracic and Vascular Sciences, University of Padua, Padua, Italy.

Disclosures: Authors have nothing to disclose with regard to commercial support.

Received for publication Jan 29, 2016; accepted for publication Feb 7, 2016; available ahead of print March 5, 2016.

Address for reprints: Vladimiro L. Vida, MD, PhD, Pediatric and Congenital Cardiac Surgery Unit, Department of

Cardiac, Thoracic and Vascular Surgery, University of Padua, Via Giustiniani, 2, 35100 Padua, Italy (E-mail: vladimiro.vida@unipd.it).

J Thorac Cardiovasc Surg 2016;151:1757-8

$0022-5223 / \$ 36.00$

Copyright (c) 2016 by The American Association for Thoracic Surgery

http://dx.doi.org/10.1016/j.jtcvs.2016.02.015
}

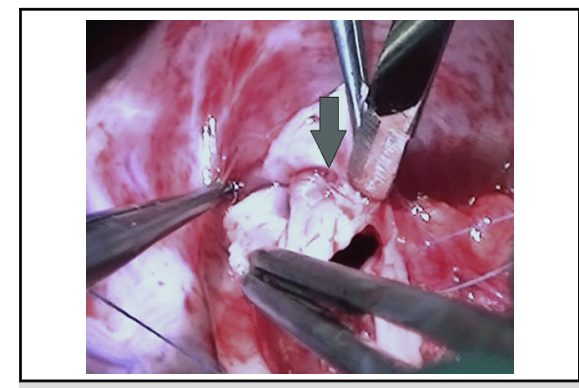

The PV leaflet delamination plasty (arrowindicates the delaminated area).

\section{Central Message}

The delamination plasty allows the extension of pulmonary valve leaflet's coaptation surface during repair of tetralogy of Fallot.

See Editorial Commentary page 1759.

\section{TTCS

Video clip is available online.

During the past decade, we embarked into a program for preserving the pulmonary valve (PV) function in selected patients during tetralogy of Fallot (TOF) repair, with the aim of preserving long-term right ventricular function. At the beginning of our experience, together with our standard early transatrial/transpulmonary repair ${ }^{1}$ an intraoperative balloon dilation of the PV annulus was performed in selected patients with milder forms of TOF. ${ }^{2}$ Progressively we treated more severe forms ( $\mathrm{PV} z$-score $\leq-3$ ) by combining additional PV plasty maneuvers, including the delamination plasty, to PV balloon dilatation. ${ }^{3-5}$ In more severe forms, the balloon splays the PV commissures apart and therefore leaflets become insufficient to cover the new whole PV annular area. The delamination PV plasty is based on achieving more leaflet tissue for coaptation by delaminating with a fine scalpel the base of each PV cusp at the hinge point, occasionally extending the delamination into the right ventricular myocardium (Figures 1 and 2). Subsequently, the extended cusps are re-suspended for creating a new PV commissure, thus achieving an acceptable PV competence (Video 1). When leaflet tissue is lacking for PV cusp reconstruction, small triangles of prosthetic patch material can be added for extending the leaflets.
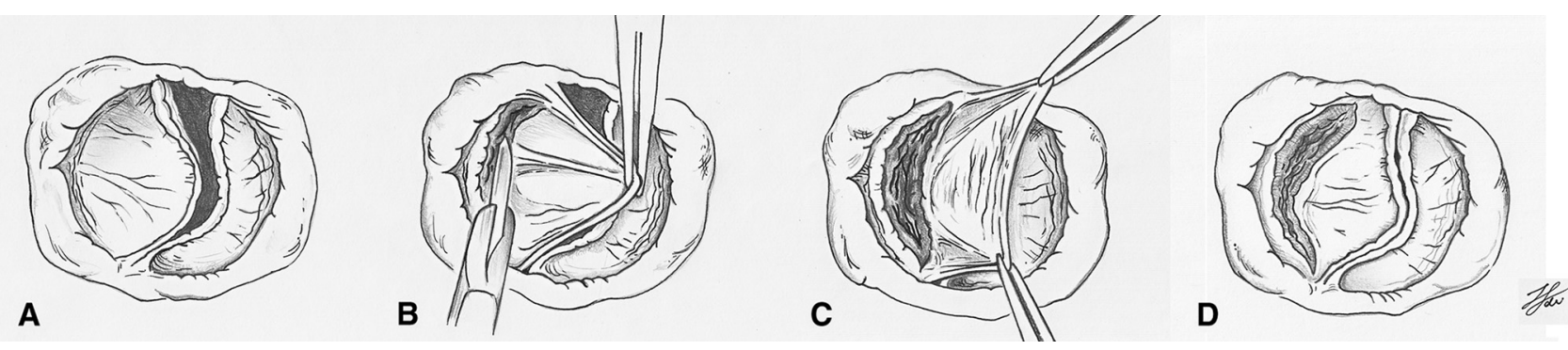

FIGURE 1. A-D, The PV leaflet delamination plasty technique after balloon dilation (arrow indicates the delaminated area that increases the leaflet coaptation surface). 

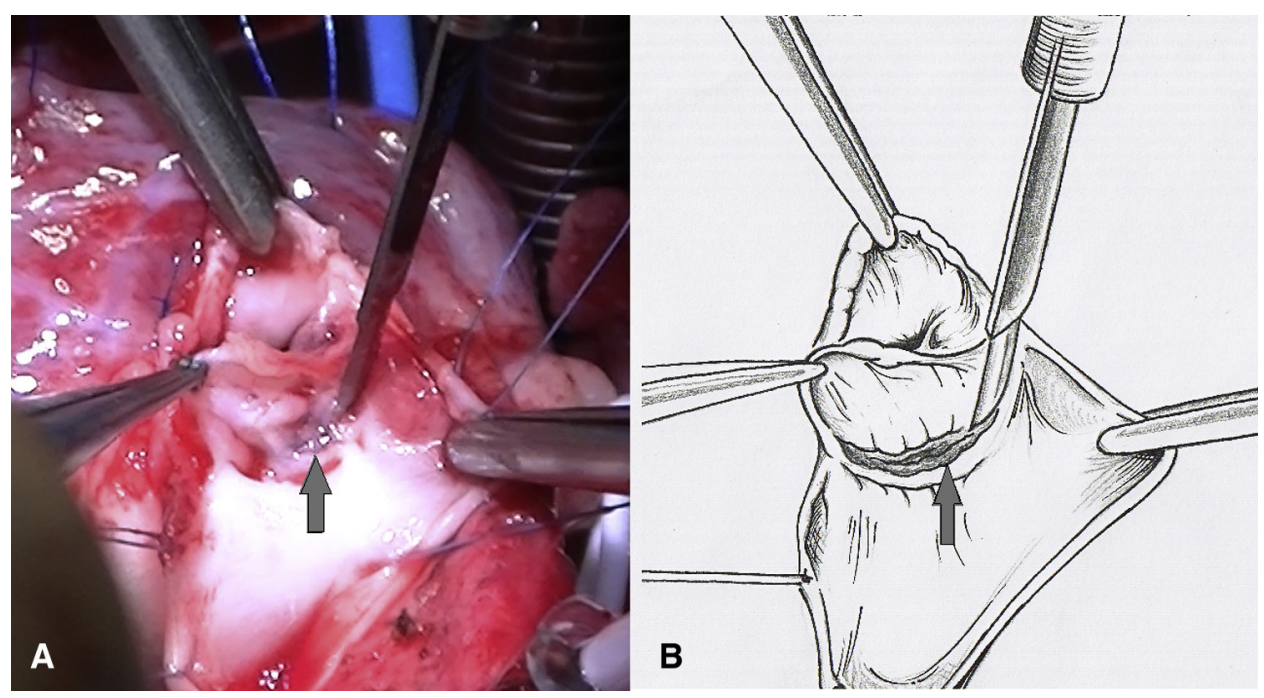

FIGURE 2. Intraoperative image of a 3.5-month-old patient with TOF and corresponding drawing showing the delamination plasty technique (arrow indicates the delaminated area).

\section{References}

1. Stellin G, Milanesi O, Rubino M, Michielon G, Bianco R, Moreolo GS, et al. Repair of tetralogy of Fallot in the first six months of life: transatrial versus transventricular approach. Ann Thorac Surg. 1995;60:S588-91.

2. Vida VL, Padalino MA, Maschietto N, Biffanti R, Anderson RH, Milanesi O, et al. The balloon dilation of the pulmonary valve during early repair of tetralogy of Fallot. Catheter Cardiovasc Interv. 2012;80:915-21.

3. Vida VL, Zucchetta F, Padalino MA, Milanesi O, Stellin G. Pulmonary valve-sparing technique in patients with tetralogy of Fallot and anomalous coronary artery crossing the infundibulum. J Heart Valve Dis. 2013;22: 425-7.

4. Vida VL, Guariento A, Castaldi B, Sambugaro M, Padalino MA, Milanesi O, et al. Evolving strategies for preserving the pulmonary valve during early repair of tetralogy of Fallot: mid-term results. J Thorac Cardiovasc Surg. 2014;147: 687-94; discussion 694-6.

5. Vida VL, Angelini A, Guariento A, Frescura C, Fedrigo M, Padalino M, et al. Preserving the pulmonary valve during early repair of tetralogy of Fallot: anatomic substrates and surgical strategies. J Thorac Cardiovasc Surg. 2015;149:1358-63.e1. 